\title{
Taurine and proliferation of lymphocytes in physically restrained rats
}

\author{
Fili Fazzino, Francisco Obregón, Lucimey Lima* \\ From $17^{\text {th }}$ International Meeting of Taurine \\ Fort Lauderdale, FL, USA. 14-19 December 2009
}

\begin{abstract}
Background: Taurine is present in lymphocytes and seems to modulate certain immune cell functions. Among the effects of taurine on these cells are protection against antioxidants and regulation of inflammatory aspects of the immune response. Stress affects antigen presentation, traffic and proliferation of leukocytes, as well as antibody and cytokine secretion. The purposes of this study were to explore the possible direct effects of taurine concentrations on lymphoproliferation and interleukins levels in control and in physical restrained rats.

Methods: Lymphocytes of male Sprague-Dawley rats, stressed by physical restrain and controls ( $5 \mathrm{~h}$ per day for 5 days) were isolated from blood by Histopaque $(1077 \mathrm{~g} / \mathrm{l})$ and differential adhesion to plastic, and then cultured $(72 \mathrm{~h})$ in the presence of different concentrations of taurine $(0.5-50 \mathrm{mM}), \beta$-alanine $(0.5-50 \mathrm{mM})$, or both, without or with the T cells mitogen, concanavalin A. Plasma and lymphocytes levels of pro-inflammatory interleukin-1 $\beta$ and anti-inflammatory interleukin-10 were respectively measured by Pierce Endogen rat ELISA Kits. Taurine in plasma and in lymphocytes were determined by HPLC.

Results: Lymphoproliferation of resting cells significantly decreased in the presence of 3 and $6 \mathrm{mM}$ taurine and increased up to control level at $12 \mathrm{mM}$ taurine. In concanavalin A-activated lymphocytes, the effect of taurine was greater. $\beta$-alanine increased lymphoproliferation in a bell shaped dose-dependent manner and decreased it in activated lymphocytes but in a lower magnitude. In combination, $\beta$-alanine impaired the effect of taurine at 3 and $6 \mathrm{mM}$. After restriction, no change in lymphoproliferation was observed at different concentrations of the amino acids without or with concanavalin A, although pro-inflammatory interleukin and taurine in plasma and in lymphocytes significantly increased.
\end{abstract}

Conclusions: Taurine affects lymphoproliferation in control rats, following a dose-dependent manner, an effect that might involve its transport into the cells. Elevation of interleukin-1 $\beta$ produced in stressed rats by physical restrain could seriously affect the immune balance, whereas taurine increase might be protective. These results suggest that taurine and taurine transport play a role in lymphoproliferation. In addition, modifications of taurine system in lymphocytes take place during restriction stress.

\section{Introduction}

Taurine (TAU) and taurine transporter (TAUT) are present in lymphocytes [1,2]. One of the functions of TAU in these cells might be related to protection against oxidants [3], regulation of pro-inflammatory cytokines in

\footnotetext{
* Correspondence: Ilima@ivic.gob.ve

Laboratorio de Neuroquímica, Centro de Biofísica y Bioquímica, Instituto Venezolano de Investigaciones Científicas-Altos de Pipe-Km 11, Carretera Panamericana, Caracas, Miranda, Venezuela

Full list of author information is available at the end of the article
}

humans and formation of taurine cloramine (Tau-Cl) [4]. Exogenous TAU was shown to possess significant anti-inflammatory properties in various in vivo and in vitro models of inflammation, and to protect the tissues by increasing the defending capacity of organs against oxidative damage in inflammatory bowel disease, pancreatitis, and gastric mucosal injury [5,6]. This antiinflammatory action of TAU was shown to be a direct result of its antioxidant effects, which inhibits lipid peroxidation and neutrophil activation [5]. The effect of 
TAU in combating oxidative damage is well known to result from its ability to scavenge hypochlorous acid generated in neutrophils in the process of phagocytosis to form the relatively harmless $\mathrm{Tau}-\mathrm{Cl}$ [7]. Tau-Cl inhibits the activation of nuclear factor $\kappa \mathrm{B}$, a potent signal transducer for inflammatory cytokines [8].

Physical restraint a well know stress model, increases oxidative processes [9], reduces T lymphocyte proliferation in response to concanavalin A (Con A), decreases the number of $\mathrm{CD} 4^{+} \mathrm{T}$ cell subpopulation without changes in $\mathrm{CD}^{+} \mathrm{T}$ cells, impairs $\mathrm{T}$ helper component of immunity [10], and could induce an elevation of plasma interkeukin 6 , tumor necrosis factor- $\alpha$ (TNF- $\alpha$ ) and interferon $\gamma$ [11-13].

The purposes of this study were to explore the possible direct effects of TAU on lymphoproliferation as well as levels of TAU, and pro- and anti-inflammatory interleukins in physically restrained rats and its controls.

\section{Methods}

\section{Animals and stress procedures}

Male Sprague-Dawley rats (Rattus norvegicus) ranging in weight from 200 to $250 \mathrm{~g}$ were obtained from the hatchery of Instituto Venezolano de Investigaciones Científicas (IVIC). The animals were housed individually in a room controlled for temperature, humidity and lighting. Commercial rat food and water were available ad libitum. All manipulations followed international ethical guide [14]. Rats were stressed by restraint in an immobilization conical tube of $50 \mathrm{ml}$ (restrainer) with ventilation holes for 5 hours and for 5 consecutive days. All stress procedures occurred from 11:00 am to 4:00 pm.

\section{Preparation of blood peripheral lymphocytes}

The rats were anesthetized with ether and blood samples were taken by intracardiac puncture between 10:00 and 11:00 am in tubes with EDTA, $1.8 \mathrm{mg} / \mathrm{ml}$. The blood was centrifuged at $1000 \mathrm{rpm}$ with a vasculant rotor for $10 \mathrm{~min}$ at room temperature. The plasma was collected for determination of interleukins and amino acid analysis, and the layer of white cells plus some red blood cells was taken and transferred to tubes with 10 $\mathrm{ml}$ of isotonic saline $0.1 \mathrm{M}$ sodium phosphate buffer $\mathrm{pH}$ 7.4 (PBS). These suspensions were placed on $3 \mathrm{ml}$ of Histopaque (Sigma) (1077 g/l). After centrifugation at $2000 \mathrm{rpm}$ for $30 \mathrm{~min}$ peripheral mononuclear cell layer was taken, washed twice with PBS and centrifuged at $1200 \mathrm{rpm}$ for $10 \mathrm{~min}$. To achieve enriched lymphocyte preparation with a minimal monocyte contamination. The resulting pellet was diluted with Roswell Park Memorial Institute Medium 1640 (RPMI) free of bovine serum albumin and incubated in a plastic flask for $45 \mathrm{~min}$ at $37^{\circ} \mathrm{C}$ and $5 \%$ of $\mathrm{CO}_{2}$. After the incubation, lymphocytes, which are non-adherent cells (80-90\%), were dislodged from adherent monocytes, transferred to plastic tubes and washed twice. The integrity of isolated lymphocytes was determined by Trypan blue exclusion test and was greater than $90 \%$.

\section{Lymphoproliferation assay}

Lymphocytes were cultured in 96 well plaques, in which 200,000 cells were placed in each one to a final volume of $200 \mu \mathrm{l}$ of RPMI medium with gentamicin $(100 \mu \mathrm{g} /$ $\mathrm{ml})$, L-glutamine $(2 \mathrm{mM})$ and $10 \%$ fetal calf serum (Gibco BRL, Maryland). The incubation was performed at $37^{\circ} \mathrm{C}, 5 \% \mathrm{CO}_{2}$ and $100 \%$ humidity for $72 \mathrm{~h}$ in the absence or in the presence of Con A at suboptimal concentration, $2 \mu \mathrm{g} / \mathrm{ml}$. TAU $(1.5-24 \mathrm{mM})$ and $\beta$-alanine ( $\beta$-Ala) (0.8-50 mM) ware added to the cultures. Proliferation was measured with 3-[4,5-dimetilazol-2-il]-2,5diphenil-tetrazolio (MTT) (Sigma, St Louis, MO) $(19,20)$. MTT was prepared in PBS, $5 \mathrm{mg} / \mathrm{ml}, 20 \mu \mathrm{l}$ was added to each well, and incubation was done for $4 \mathrm{~h}$ at $37^{\circ} \mathrm{C}$. Then, $100 \mu \mathrm{l}$ of solution was extracted and $100 \mu \mathrm{l}$ of $\mathrm{HCl} 0.04 \mathrm{~N}$ in isopropanol was added. After mixing, the plaque was read in a GENios lector (Tecan) at $570 \mathrm{~nm}$ with the Program Magellan.

Measurement of plasma interleukin-1 $\beta$ and interleukin-10 Plasma collected for interleukin-1 $\beta$ (IL-1 $\beta$ ) and interleukin-10 (IL-10) assays was stored at $-80^{\circ} \mathrm{C}$. The levels of IL-1 $\beta$ and IL-10 were measured by ELISA Endogen kits (Pierce Endogen, Cambridge, MA) following the manufacturer's instructions. Briefly, $100 \mu \mathrm{l}$ of samples were dispensed into 96 wells coated with rat IL-1 $\beta$ or IL-10 antibody and incubated for 2 hours at room temperature. After extensive washing, $100 \mu \mathrm{l}$ of the biotinylated anti-IL-1 $\beta$ (or IL-10) were added to each well, and plates were incubated for $30 \mathrm{~min}$ at room temperature. The wells were again washed 5 times, $100 \mu \mathrm{l}$ of Streptavidin-HRP was added and incubation was done for 30 min. 3,3',5,5'-tetramethylbenzidine (TMB) $(100 \mu \mathrm{L} /$ well $)$ was used as the chromogen for the colorimetric assay. The reaction was stopped by adding $100 \mu \mathrm{l} /$ well of stop solution and the absorbance was read at $450 \mathrm{~nm}$. The levels of ILs are expressed as pg/ml.

\section{Determination of taurine}

TAU in plasma and in lymphocytes was determined by high performance liquid chromatography (HPLC) with fluorescent detection employing a modified method (16). The HPLC system consisted of a Waters 2690 Separation System and a Shimadzu RF-551 fluorescent detector. A Sulpeco LC-18 column 4.6 X $100 \mathrm{~mm}, 5 \mu \mathrm{m}$ was employed for amino acid separation. Platelet poor plasma, $300 \mu \mathrm{l}$, was acidified with $50 \mu \mathrm{l}$ of $20 \%$ sulfosalicylic acid. Centrifugation was carried out at 17,000 rpm 
for $20 \mathrm{~min}$, at $4^{\circ} \mathrm{C}$, and supernatant was kept at $80^{\circ} \mathrm{C}$ until chromatographic analysis. Immediately before injection, $50 \mu \mathrm{l}$ of the supernatants plus $150 \mu \mathrm{l}$ of potassium borate buffer $\mathrm{pH} 10.4$ and $200 \mu \mathrm{l}$ of the mixture: $25 \mathrm{mg}$ o-phtaldehyde, $500 \mu \mathrm{l}$ methanol, $25 \mu \mathrm{l} \beta$-mercaptoethanol $(1 \mathrm{~g} / \mathrm{ml})$, and $4.5 \mathrm{ml} 0.4 \mathrm{M}$ potassium borate buffer $\mathrm{pH}$ 10.4 was used for derivatization. Then, $15 \mu \mathrm{l}$ of the derivatized preparation were injected into the chromatographic system. The levels of amino acids were calculated from the area under the curve of samples and external standards with program Millenium, and expressed as $\mathrm{nmol} / \mathrm{ml}$.

\section{Analysis of data}

Data are expressed as the arithmetic mean \pm standard error of the mean (SEM). Differences were statistically analyzed using the Student's t-test. Statistical significance was considered if $\mathrm{P}<0.05$. Data management and statistical analysis were conducted employing the program Microsoft Office Excel 2007.

\section{Results and discussion}

\section{Lymphoproliferation}

Figure 1A shows that lymphoproliferation of control rats significantly decreased in the presence of $3 \mathrm{mM}$ TAU and reached basal levels at $6 \mathrm{mM}$ TAU. While in Con A- activated lymphocytes, there is also a significant decrease a $3 \mathrm{mM}$, but it remains low in the following concentrations. In restrained rats (Figure 1B) there were no statistical changes in activated lymphocytes, and resting showed a significant increase at 3 and $6 \mathrm{mM}$, but returned to basal values at greater concentrations. The Figure 2 shows that to values above $6 \mathrm{mM} \beta$-Ala the lymphoproliferation significantly increased In Con

\section{A)}

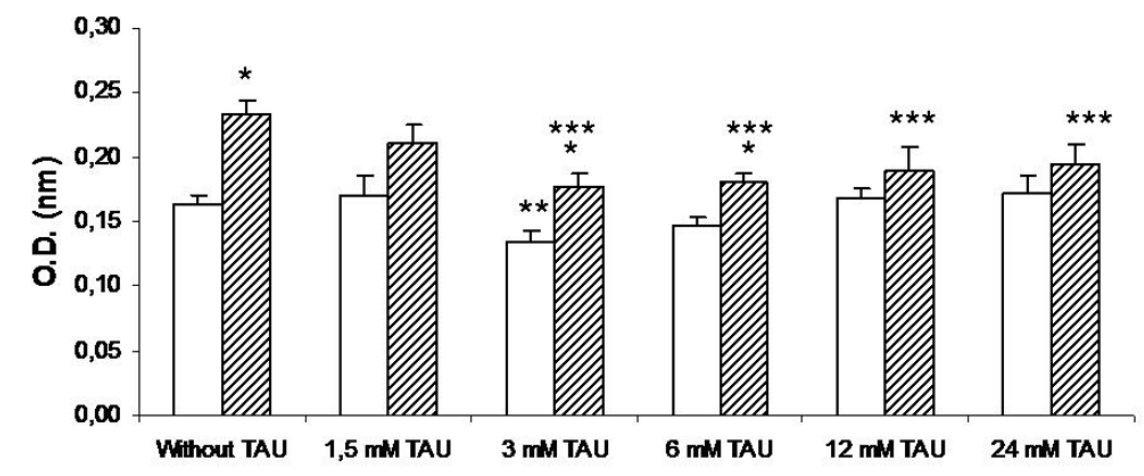

\section{B)} $\square$ Without TAU $\square \operatorname{Con} A$

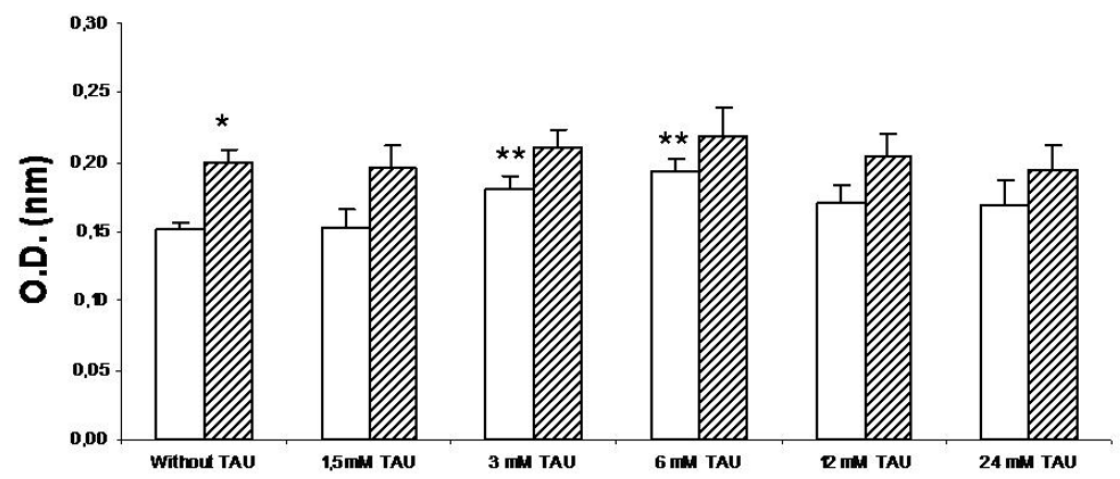

Figure 1 Effect of taurine (TAU) on lymphoproliferation in the absence and in the presence of concanavalin $A$ (Con A), A) in control rats, and $\mathrm{B}$ ) in physical restrained rats. Each value represents the mean $\pm \mathrm{SEM}, n=6 .{ }^{*} \mathrm{P}<0.05$ respecting corresponding Basal. ${ }^{*} \mathrm{P}<0.05$ respecting Without TAU Basal. ${ }^{* * *} \mathrm{P}<0.05$ respecting Without TAU Con $\mathrm{A}$. 


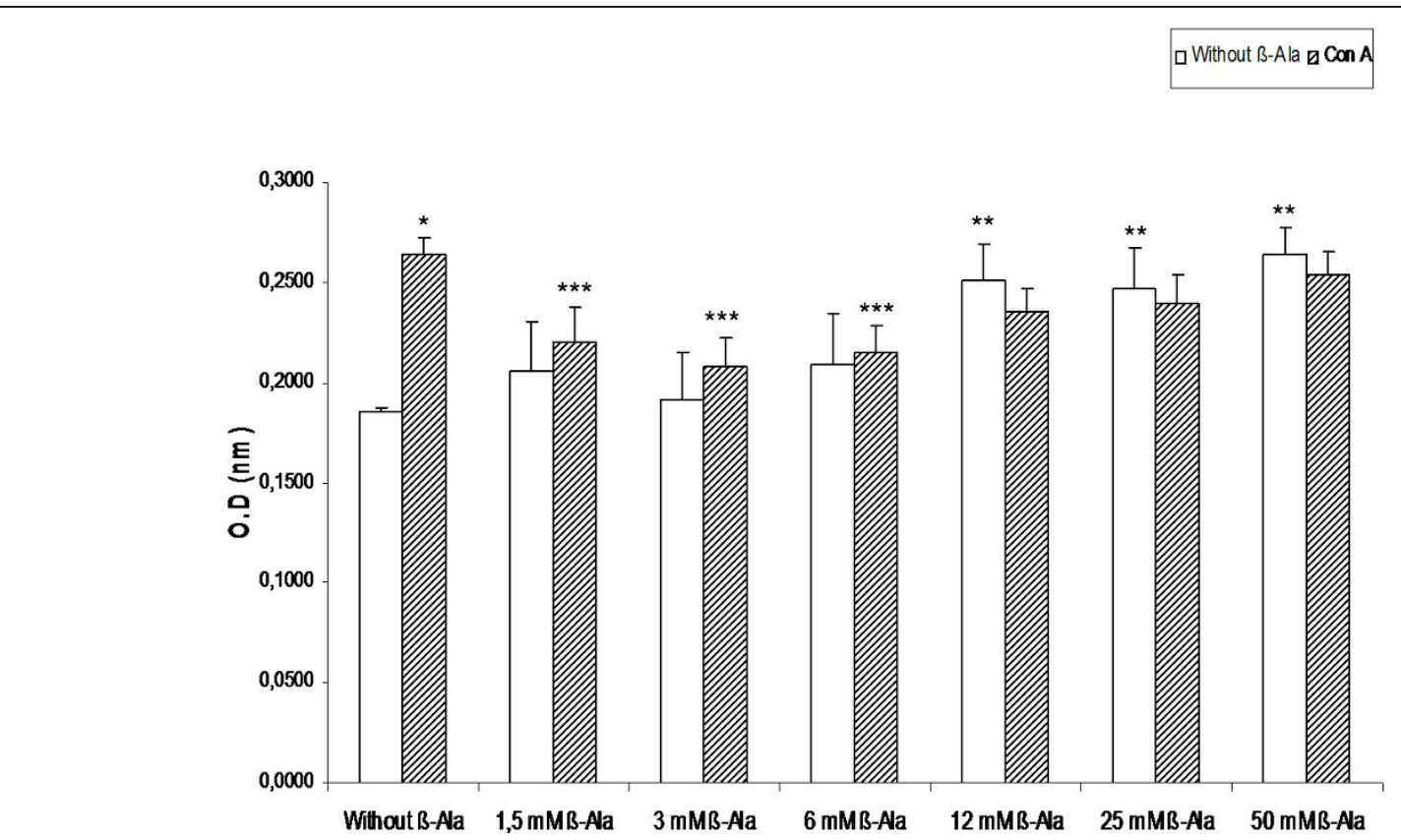

Figure 2 Effect of $\beta$-alanine ( $\beta$-Ala) on lymphoproliferation in the absence and in the presence of concanavalin $A$ (Con $A$ ) in control rats. Each value represents the mean $\pm \mathrm{SEM}, n=6 .{ }^{*} \mathrm{P}<0.05$ respecting corresponding Basal. ${ }^{* *} \mathrm{P}<0.05$ respecting Without $\beta$-Ala Basal. ${ }^{* * *} \mathrm{P}$ $<0.05$ respecting Without $\beta$-Ala Con $\mathrm{A}$.

A- activated lymphocytes, there was a significant decrease between 1,5 and $6 \mathrm{mM}$ and reached basal levels unactivated. However, at higher concentrations when the values of lymphoproliferation were again statistically similar to basal of Con A, we observed that the effect decreased to a lesser extent in Con A-activated lymphocytes (Figure 2).

Protein kinase $\mathrm{C}(\mathrm{PKC})$ isoforms plays an important role in lymphoproliferation. PKC- $\theta$, is a crucial regulator of T-cell activation and proliferation as well as of cytokine production [15-17]. Moreover, PKC- $\alpha$ is also involved in T-cell proliferation acting upstream of PKC$\theta[18,19]$. In addition, Tau has been shown to affect PKC isoforms, regulating their activity an expression in a concentration-dependent manner [20,21], and it is possible that the observed response in lymphoproliferation is due to the effect of Tau on PKC isoforms and/or inhibition of the nuclear translocation of NF-kappaB by inhibition of PKC- $\alpha$ expression [19]. However, TAU also regulates the phosphorylation of TAUT, through $\mathrm{PKC}$ as an adaptive response to changes in TAU availability [22-24], so maybe TAUT plays an important role in the lymphoproliferation.

On the other hand, since previous studies show that inhibitors of PKC suppress mitogen induced T-cell proliferation [25], it is possible that Tau acts as an inhibitor of $\mathrm{PKC}$ at concentrations above $3 \mathrm{mM}$, and therefore the effect in lymphoproliferation is more prominent in Con A activated- lymphocytes.
Previous studies have demonstrated that physical restrain decreases peripheral blood lymphocyte and mitogen-induced proliferation in rats and produces changes in $\mathrm{T}$ cell functional capacity $[26,10]$. In the present study, decreased response of lymphoproliferation was not observed in restrained rats. In addition, no differences were present with variable TAU concentration which could indicate that immune modifications due to physical restrain might be regulated by TAU, possibly through its effect on PKC isoforms.

To better assess the effect of TAUT on the lymphocyte proliferation the TAUT antagonist, $\beta$-Ala, was used [27]. In these experiments, at low concentrations of $\beta$ Ala lymphoproliferation remains at values similar to basals, but with increasing concentrations, lymphoproliferation significantly increased. It might be that incomplete inhibition of TAUT at low concentrations of $\beta$-Ala, in contrast to the effects observed at higher concentrations of this amino acid could be responsible for the differential modulation of lymphocytes proliferation. However, Con A-treated lymphocytes displayed a resistance to the influences of TAU or $\beta$-Ala, probably indicating a particular condition of TAUT due to the unspecific activation by the mitogen.

\section{Plasma levels of interleukine- $1 \beta$ and interleukine-10}

The concentration of the proinflammatory IL- $1 \beta$ significantly increased in restrained rats, reaching concentrations more than double those of controls, while the 
anti-inflammatory IL-10 remained unchanged in controls and in restrained rats (Fig. 3).

Physical restraint is known to activate hypothalamicpituitary-adrenal (HPA) axis, resulting in transiently increased release of glucocorticoids and IL-6 [28,29]. Findings by in vitro studies indicate that IL- 6 produces upregulation of IL- $1 \beta$ mRNA in human T cells, and this positive feedback by IL- 6 on IL- $1 \beta$ secretion occurs after or during stress as a mechanism of partially reducing the downregulatory effect of corticosterone on IL-1 $\beta$ [12]. Moreover, IL-1 $\beta$, together with TNF- $\alpha$ and IL- 6 influence the HPA axis, resulting in increased levels of glucocorticoids in physically restrained rats $[30,31]$. On the other hand, IL- 6 is a pleiotropic interleukin that has multiple functions, including stimulatory effects on proliferation and differentiation of lymphocytes [32], and could be one of the factors influencing lymphoproliferation.

\section{Plasma and lymphocytes taurine concentration}

Figure $4 \mathrm{~A}$ and $4 \mathrm{~B}$ represent the levels of TAU in plasma and in lymphocytes, respectively, which significantly increased in restrained rats. Physical restraint leads to hyper-oxidant reaction, and hence in an imbalance between pro-oxidant and anti-oxidant forces [9], as well as increase in proinflamatory cytokines [13]. It is possible that the increase of plasma TAU could be involved in protection against oxidants and in regulation of proinflammatory cytokines production by the formation of Tau-Cl.

Previous studies have shown that high concentrations of TAU reduced the expression, activity and nuclear localization of TAUT, whereas low levels increase them [23]. This is due to TAU affects the phosphorylation of specific proteins through PKC $[22,33]$, TAUT, which is

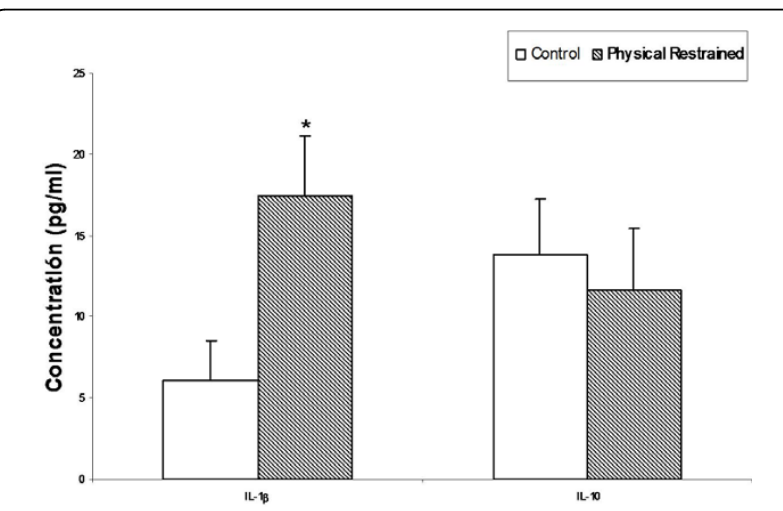

Figure 3 Plasma concentration of the pro-inflammatory interleukin-1 $\beta$ (IL-1 $\beta$ ), and the anti-inflammatory interleukin-10 (IL-10) in Control and in Physical Restrained rats. Each value represents the mean $\pm \mathrm{SEM}, n=6$. $\mathrm{P}<0.05$ respecting Control.

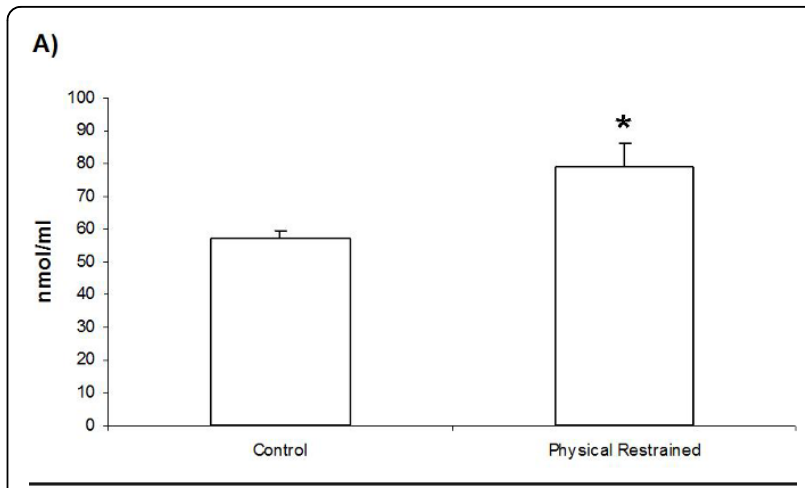

B)

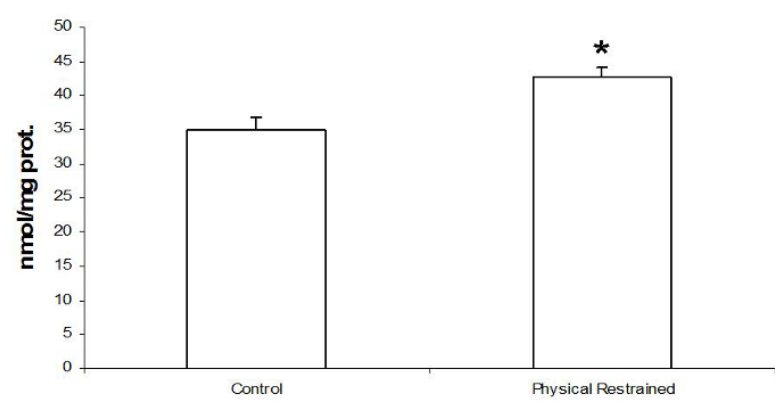

Figure 4 A) Plasma, and B) lymphocyte concentrations of taurine in Control and in Physical Restrained rats. Each value represents the mean $\pm \mathrm{SEM}, n=6$. $\mathrm{P}<0.05$ respecting Control.

regulated by PKC phosphorylation in serine 322 at the post-translational level [34] as an adaptive response to changes in TAU availability. It might be that TAUT could be lower in restrained rats, then produce a temporal increase of TAU in the circulation as a regulatory response. Moreover, the increased values of TAU in lymphocytes could be linked to changes in TAUT.

At the present, studies on TAUT capacity and expression are undertaken in restrained rats.

\section{Conclusions}

Results in culture at different conditions suggest that TAU system plays a differential role in lymphoproliferation, related to concentration, and that physical restraint produces alterations that influence TAU effects. Concentrations of IL- $1 \beta$ were elevated in plasma of rats after physical restraint, which indicate modifications during stress that could trigger pathological changes. The significant increase of TAU levels in plasma and in lymphocytes are probably related to known protective effects of TAU, and might be the result of TAUT changes.

List of abbreviations

TMB: 3,3',5,5'-tetramethylbenzidine ; MTT: 3-[4,5-dimetilazol-2-il]-2,5-dipheniltetrazolio ; $\beta$-Alanine ( $\beta$-Ala); Con A: Concanavalin A; HPLC: High 
performance liquid chromatography; HPA: Hypothalamic-pituitary-adrenal; IVIC: Instituto Venezolano de Investigaciones Científicas; IL: Interleukin; PBS: Isotonic saline $0.1 \mathrm{M}$ sodium phosphate buffer pH 7.4; PKC: Protein kinase C; RPMI: Roswell Park Memorial Institute Medium 1640; TAU: Taurine; Tau-Cl: Taurine cloramine; TAUT: Taurine transporter; TNF- $\alpha$ : Tumor necrosis factor- $\alpha$.

\section{Acknowledgements}

Supported by Fondo Nacional de Ciencia, Tecnología e Innovación (FONACIT G-1387), Venezuela.

This article has been published as part as part of Journal of Biomedical Science Volume 17 Supplement 1, 2010: Proceedings of the 17th International Meeting of Taurine. The full contents of the supplement are available online at http://www.jbiomedsci.com/supplements/17/S1.

\section{Authors' contributions}

FF carried out the experiments, made calculations, participated in the discussion of results, and did most of the writing. FO carried out the HPLC analysis of plasma and lymphocytes TAU levels. LL conceived the study, made the contribution for design, analysis, interpretation of data, discussion, and final writing.

\section{Competing interests}

The authors have non-financial competing interests in an exclusive academic way.

Published: 24 August 2010

\section{References}

1. Vinton NE, Laidlaw SA, Ament ME, Kopple JD: Taurine concentrations in plasma, blood cells, and urine of children undergoing long-term total parenteral nutrition. Pediatr Res 1987, 21:399-403.

2. Fazzino F, Urbina M, Mata S, Lima L: Taurine transport and transporter localization in peripheral blood lymphocytes of controls and major depression patients. Adv Exp Med Biol 2006, 583:423-436.

3. Learn DB, Fried VA, Thomas EL: Taurine and hypotaurine content of human leukocytes. J Leukoc Biol 1990, 48:174-182.

4. Grimble RF: The effects of sulfur amino acid intake on immune function in humans. J Nutr 2006, 136:1660S-1665S.

5. Kim S, Kim H, Yang W, Kim B: Protective effect of taurine on indomethacin-induced gastric mucosal injury. Taurine, Plenum Press, New YorkR.J. Huxtable, J. Azuma, K. Kuriyama, M. Kakagawa and A. Baba 1996, 147-155.

6. Marcinkiewicz J, Grabowska A, Bereta J, Stelmaszynska T: Taurine chloramine, a product of activated neutrophils, inhibits the generation of nitric oxide and other macrophage inflammatory mediators. I Leukoc Biol 1995, 58:667-674.

7. Marquez L, Dunford $\mathrm{H}$ : Chlorination of taurine by myeloperoxidase; kinetic evidence for an enzyme-bound intermediate. J. Biol. Chem 1994, 269:7950-7956.

8. Schuller-Levis G, Mehta PD, Rudelli R, Sturman J: Immunologic consequences of taurine deficiency in cats. J Leukoc Biol 1990, 47:321-331.

9. Zafir A, Banu N: Induction of oxidative stress by restraint stress and corticosterone treatments in rats. Indian J Biochem Biophys 2009, 46:53-58.

10. Frick LR, Barreiro Arcos ML, Rapanelli M, Zappia MP, Brocco M, Mongini C, Genaro AM, Cremasch GA: Chronic restraint stress impairs T-cell immunity and promotes tumor progression in mice. Stress 2009, 12:134-43.

11. Curtin NM, Boyle NT, Mills K, Connor TJ: Psychological stress suppresses innate IFN- $\gamma$ production via glucocorticoid receptor activation: Reversal by the anxiolytic chlordiazepoxide. Brain, Behavior, and Immunity 2009, 23:535-547.

12. Smith C, Wilson NW, Louw A, Myburgh KH: Illuminating the interrelated immune and endocrine adaptations after multiple exposures to short immobilization stress by in vivo blocking of IL-6. Am J Physiol Regul Integr Comp Physiol 2007, 292:R1439-R1447.

13. Liu Y-L, Bi H, Chi SM, Fan R, Wang YM, Ma XL, Chen YM, Luo WJ, Pei JM, Chen JY: The effect of compound nutrients on stress-induced changes in serum IL-2, IL-6 and TNF-a levels in rats. Cytokine 2007, 37:14-21.

14. Institute of Laboratory Animals Research: Guide for the Care and Use of Laboratory Animals. 1996, Spanish version México 2002.
15. Manicassamy S, Gupta S, Sun Z: Selective function of PKC- $\theta$ in T cells. Cell Mol Immunol 2006, 3:263-270

16. Sun Z, Arendt CW, Ellmeier W, Schaeffer EM, Sunshine MJ, Gandhi L, et al: PKC- $\theta$ is required for TCR-induced NF- $\kappa$ B activation in mature but not immature T lymphocytes. Nature 2000, 404:402-407.

17. Pfeifhofer C, Kofler K, Gruber T, Tabrizi NG, Lutz C, Maly C, et al: Protein kinase $\mathrm{C} \theta$ affects $\mathrm{Ca}^{2+}$ mobilization and NFAT cell activation in primary mouse T-cells. J Exp Med 2003, 197:1525-1535.

18. Iwamoto T, Hagiwara M, Hidaka H, Isomura T, Kioussis D, Nakashima I: Accelerated proliferation and interleukin-2 production of thymocytes by stimulation of soluble anti-CD3 monoclonal antibody in transgenic mice carrying a rabbit protein kinase C $\alpha$. J Biol Chem 1992, 267:18644-18648.

19. Trushin SA, Pennington KN, Carmona EM, Asin S, Savoy DN, Billadeau DD, et al: Protein kinase $\mathrm{C} \alpha(\mathrm{PKC} \alpha)$ acts upstream of PKC $\theta$ to activate $\mathrm{I} \kappa \mathrm{B}$ kinase and NF- $\kappa$ B in T lymphocytes. Mol Cell Biol 2003, 23:7068-7081.

20. Trenkner E, Liu D, Harris C, Sturman J: Regulation of protein kinase $C$ activity by taurine and beta-alanine during excitotoxicity in cat and mouse cerebellar cultures. Adv Exp Med Biol 1994, 359:309-316.

21. Wang YC, Guan FY, Li H, Yang SJ: Anti-proliferation action of taurine on rat cardiac fibroblast through inhibiting protein kinase Calpha expression. Yao Xue Xue Bao 2009, 44:591-596.

22. Lima L, Cubillos S: Taurine Might Be Acting as a Trophic Factor in the Retina by Modulating Phosphorylation of Cellular Proteins. Journal of Neuroscience Research 1998, 53:377-384.

23. Voss J, Pedersen S, Christensen S, Lambert I: Regulation of the expression and subcellular localization of the taurine transporter TauT in mouse NIH3T3 fibroblasts. Eur. J. Biochem 2004, 271:4646-4658.

24. Han X, Patters AB, Jones DP, Zelikovic I, Chesney RW: The taurine transporter: mechanisms of regulation. Acta Physiol (Oxf) 2006, 187:61-73.

25. Evenou JP, Wagner J, Zenke G, Brinkmann V, Wagner K, Kovarik J, Welzenbach KA, Weitz-Schmidt G, Guntermann C, Towbin H, Cottens S, Kaminski S, Letschka T, Lutz-Nicoladoni C, Gruber T, Hermann-Kleiter N, Thuille N, Baier G: The potent protein kinase C-selective inhibitor AEB071 (sotrastaurin) represents a new class of immunosuppressive agents affecting early T-cell activation. J Pharmacol Exp Ther 2009, 330:792-801.

26. Frick LR, Rapanelli M, Bussmann UA, Klecha AJ, Arcos ML, Genaro AM, Cremaschi GA: Involvement of thyroid hormones in the alterations of Tcell immunity and tumor progression induced by chronic stress. Biol Psychiatry 2009, 65:935-942.

27. Shaffer JE, Kocsis JJ: Taurine mobilizing effects of beta alanine and other inhibitors of taurine transport. Life Sci 1981, 28:2727-2736.

28. Zhou D, Kusnecov AW, Shurin MR, DePaoli M, Rabin BS: Exposure to physical and psychological stressors elevates plasma interleukin 6: relationship to the activation of hypothalamic-pituitary-adrenal axis. Endocrinology 1993, 133:2523-2530.

29. Hideyuki N, Nobuyuki S, Yuhji A, Naomi O, Yasuhiro K, Chiharu K: Restraint stress elevates the plasma interleukin- 6 levels in germfree mice. Journal of Neuroimmunology 2001, 115:46-52.

30. Panzer S, Madden M, Matsuki K: Interaction of IL-1 beta, IL-6 and tumour necrosis factor-alpha (TNF-_) in human T cells activated by murine antigens. Clin Exp Immunol 1993, 93:471-478.

31. Path G, Bornstein SR, Spath-Schwalbe E, Scherbaum WA: Direct effects of interleukin-6 on human adrenal cells. Endocr Res 1996, 22:867-873.

32. Schimpl A, Wecker E: Replacement of T cell function by a T cell product. Nat New Biol 1972, 237:15-17.

33. Lombardini JB, Props C: Effects of kinase inhibitors and taurine analogues on the phosphorylation of specific proteins in mitochondrial fractions of rat heart and retina. Adv Exp Med Biol 1996, 403:343-350.

34. Han X, Budreau AM, Chesney RW: Ser-322 is a critical site for PKC regulation of the MDCK cell taurine transporter (pNCT). J Am Soc Nephrol 1999, 10:1874-1879.

doi:10.1186/1423-0127-17-S1-S24

Cite this article as: Fazzino et al:: Taurine and proliferation of lymphocytes in physically restrained rats. Journal of Biomedical Science 2010 17(Suppl 1):S24 